\title{
Coal gasification ash and Weathered fly ash, as partial replacement of Portland cement - effect on selected durability properties of concrete
}

\author{
Dikeledi Maboea and Mike Otieno \\ School of Civil and Environmental Engineering, University of the Witwatersrand, Johannesburg
}

\begin{abstract}
This study uses Sasol ashes as cement extenders to contribute to the technology of partially replacing Portland cement by mass. There are two types of Sasol ashes; coal gasification ash (CGA) and weathered fly ash (WFA) produced from low grade coal. These ashes are disposed of by Sasol with no specific utilisation. In this investigation, PC will be partially replaced by mass with WFA, CGA and FA at $10 \%, 15 \%$ and $30 \%$ proportions for each type of ash. The durability indices will be measured and compared for all blended specimen (PC/WFA, PC/CGA and PC/FA). A 100\% Portland cement specimen will be used as a control. The durability properties will be used to determine the potential of Sasol ashes being used as a cement extender.
\end{abstract}

\section{Introduction}

Concrete is a commonly-used construction material, known for its strength and durability properties. The durability of concrete is evident in its ability to withstand the exposure environment over the design life, without undue loss of serviceability or need for major repair [1]. The strength and durability of concrete in its hardened state stems from the complex matrix of stone, sand, cement, admixtures and water.

Sand, stone and water are natural resources with limited manipulation required to be used to produce concrete. Portland cement (PC) is the most common type of cement available in the market. In 2015, the global cement consumption average was approximately $513 \mathrm{~kg}$ per capita [9].

The high consumption of $\mathrm{PC}$ results in the increased emission of $\mathrm{CO}_{2}$ as a by-product during the production process. It has been estimated that for one ton of PC produced, approximately one ton of $\mathrm{CO}_{2}$ is emitted [5]. The continued saturation of $\mathrm{CO}_{2}$ in the atmosphere has been linked to global warming which has resulted in environmental concerns - extreme climatic changes, melting of the glaciers, droughts, and extinction of vulnerable species [6]. The protection and preservation of the environment has become one of the most important concerns worldwide.

The construction industry and its stakeholders have therefore recognised the necessity to reduce $\mathrm{CO}_{2}$ emissions caused by the production of PC. This will subsequently minimize the rate of $\mathrm{CO}_{2}$ saturation in the atmosphere, combating global warming. Methods considered to reduce $\mathrm{CO}_{2}$ emissions as a result of cement have been to use alternative binders, partial replacement of cement in concrete mixes, optimizing reinforcement, prolonging the service life as well as reusing and recycling [19].

The partial replacement of $\mathrm{PC}$ has been considered as one of the viable methods to curb the rate of $\mathrm{CO}_{2}$ concentration. This method shall be the basis of this investigation. The partial replacement of $\mathrm{PC}$ has the potential to reduce the demand of PC. A portion of PC is replaced with cement extenders; fly ash (FA), ground granulated blast-furnace slag (GGBS) and silica fume (SF). FA is collected from the exhaust flows of furnaces burning finely ground coal. GGBS is a by-product of the iron-making process and SF is the condensed vapour byproduct of the ferro-silicon smelting process. Cement extenders are materials that have cementing properties when used with PC [4].

The South African construction sector mainly uses FA from coal power stations, and GGBS. The FA has been researched and developed as a cement extender $[7 ; 8 ; 17]$. The mineralogical composition of FA was studied by $[10$,$] using the X-ray diffraction (XRD)$ analysis. They determined that FA consists mainly of an aluminium silicate glass (the active, pozzolanic component in the FA), mullite $\left(\mathrm{Al}_{6} \mathrm{Si}_{2} \mathrm{O}_{13}\right)$, low-quartz $\left(\mathrm{SiO}_{2}\right)$, as well as some quicklime $(\mathrm{CaO})$.

Similarities were observed by [13] between FA and Sasol ashes mineralogical composition, which led to the belief that Sasol ashes could potentially be used as cement extenders. Sasol ashes are by-products from the gasification and combustion processes carried out on coal. There are two types of Sasol ashes; coal gasification ash (CGA) which is coarse and disposed in

\footnotetext{
* Corresponding author: nkele6@gmail.com
} 
dry form, and weathered fly ash (WFA) which is a combination of the fine ashes from both the gasification and combustion process disposed in a slurry form.

CGA is produced from the Saso-Lurgi gasification process to produce synthesis gas; it is a clinker ash with heterogeneous texture varying from fine material to large irregularly shaped aggregates [14]. WFA is a combination of approximately $83 \%$ power station fly ash and $17 \%$ both gasification ash and bottom ash fines (particles $<250 \mu \mathrm{m}$ ), hydraulically disposed of in a slurry form or dry dumped into a coal ash dam [11].

Sasol Ltd, South Africa's liquid fuel producer, approximately uses 35 million tons of coal for its processes resulting in 7.5 million tons of Sasol ashes annually[13]. The Sasol ashes are dumped in waste heaps on arable land. Sasol Ltd is interested in determining positive utilization of the Sasol ashes.

This investigation will replace 10,15 and $30 \%$ of PC by mass with WFA, CGA, and FA. Comparison between the blended specimen and $100 \%$ PC specimen will allow the understanding of the properties of Sasol ashes. Measuring the durability of the specimen assist in determining if Sasol ashes are suitable as cement extenders.

\section{Research Significance}

Sasol is interested in identifying beneficial utilisation opportunities for their by-product, Sasol ashes [13]. An estimated 1200 tons of ash is produced per hour from Sasol's production processes [13]. Disposal of these ashes has environmental and financial implications [23].

The ashes have been found to have toxic trace elements that could potentially leach, polluting the surface and groundwater [12]. The fineness of the ash particles make it prone to dust, potentially coating vegetation detering photosynthesis. Land has to be acquired for use as disposal site, this generates no income for the company [12]. A waste license is required for the storage of waste, certain criterion need to be fulfilled to the satisfaction of the Department of Environmental Affairs (DEA). The management and upkeep of the site to ensure compliance with the DEA incurs cost.

Using Sasol ashes as a cement extender can reduce the negative impact on the environment and Sasol Ltd finances. The Sasol ashes would generate revenue for Sasol. The need to acquire more land for disposal would be greatly reduced. The ashes produced would not be left to accumulate but would be utilised, freeing up land for other social, economic or environmental uses.
Sideris \& Konsta-Gdoutos (1996) found that using FA in PC reduces the amount of water required to achieve the same workability and strength as a pure PC concrete mix, thus lessening the strain on water scarcity. The cement industry could potentially exploit the chemical and physical properties identified in FA, by using Sasol ashes.

FA has been found to improve the durability of concrete, even at low margins [8]. Water absorption, sorptivity and permeability was found to become generally low. The fines of the FA occupy the voids left over by the aggregate and PC, making the concrete less permeable. Gas permeability is on average slightly lower, if not consistent with PC concrete. Rate of carbonation and chloride ingress resistance by diffussion or absorption is slightly higher. Reinforcement protection for equal cover compared to $\mathrm{PC}$ concrete is better, due to the formation of the a denser barrier.

\section{Methodology}

This investigation is interested in the durability of the concrete with PC partially replaced by Sasol ashes. The experimental variables in this investigation are:

- Cement extenders: fly ash (FA), weathered fly ash (WFA) and coal gasification ash (CGA). The properties of PC concrete will be used as a control.

- Partial replacement of cement: $10 \%, 15 \%$ and 30\%

- Water-to-binder ratio: 0.40 and 0.50

Test procedures, as described in the relevant South African Standards, shall be carried out on specimens with $0 \%, 10 \%, 15 \%$ and $30 \%$ fly ash and Sasol ashes respectively, as follows:

- Slump test - workability/consistence of concrete mix-SANS 5862-1:2006;

- Durability index tests - to determine the chloride conductivity and oxygen permeability - Parts 1, 2, and 4 have been formalised as SANS Test Methods: SANS 3001-CO3-1:2015, SANS 3001CO3-2:2015, and SANS 3001-CO3-3:2015, respectively. Part 3, the Water Sorptivity and Porosity Test will be determined using the Durability Index Testing Procedure Manual [2].

The high-level methodology of this investigation is indicated in Figure 1. The flow chart indicates the preparation of concrete mix to be tested for their fresh and hardened properties. The report will be prepared in conjunction with lab testing. 


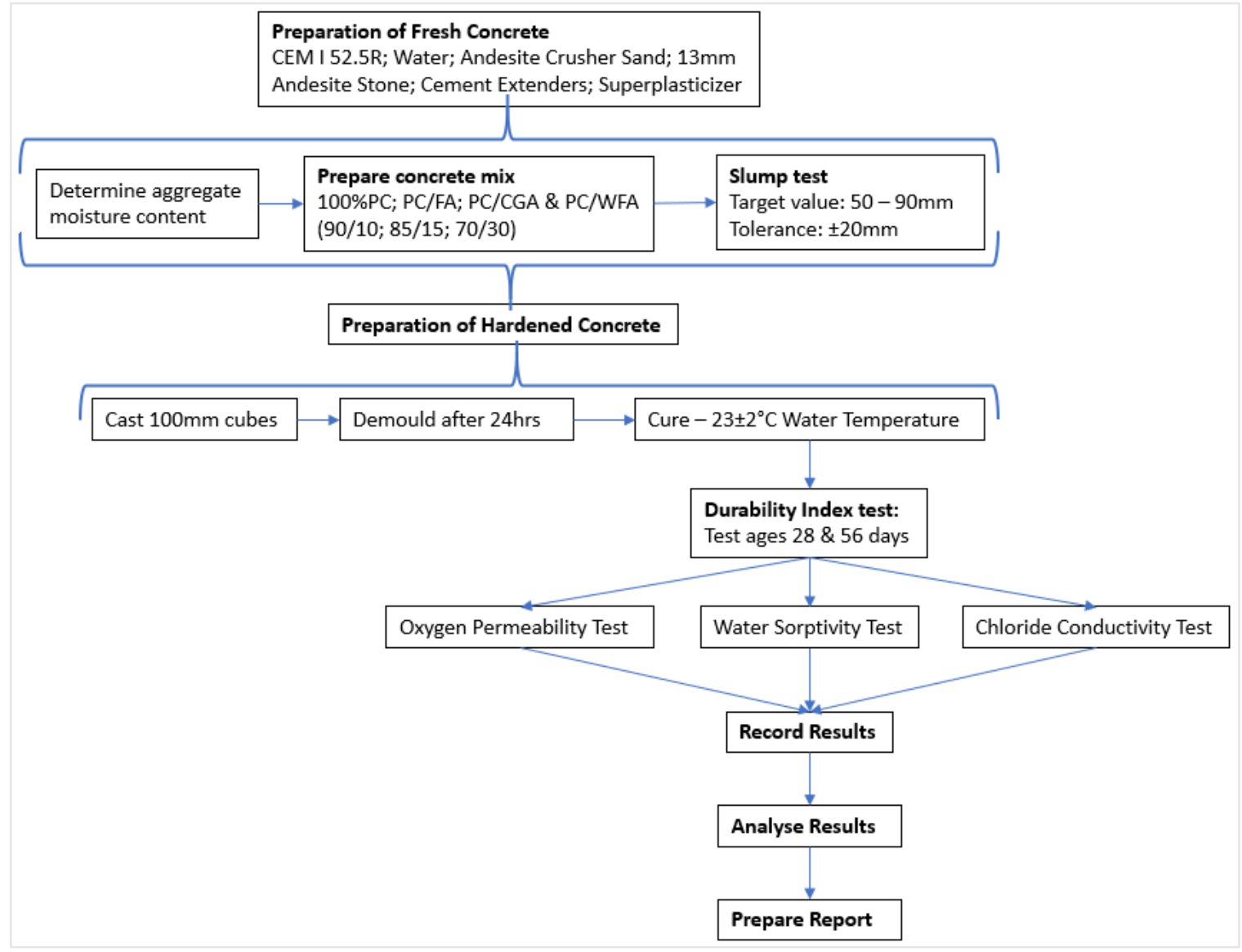

Figure 1: Investigation Flow Chart

\section{Brief description of the durability index tests}

\subsection{Oxygen permeability test}

The Oxygen Permeability Index (OPI) test consists of measuring the pressure decay of oxygen passing through a $30-\mathrm{mm}$ thick slice of a (typically) 68 to $70-\mathrm{mm}$ diameter core of concrete placed in a falling head permeameter. The permeameter is purpose built, it can be pressurised using oxygen gas, for the test to record regular measurements of pressure being taken with time [20]. Figure 2 below illustrates the oxygen permeameter. The test is very useful to assess the state of compaction, presence of bleed voids and channels, and the degree of interconnectedness of the pore structure [1]. A good degree of correlation has been found between OPI values and carbonation depths after natural exposure. The higher the OPI value the lower the carbonation value. A higher OPI value indicates a higher impermeability and potentially a higher quality concrete [1].

\subsection{Water sorptivity test}

Cores used to determine the OPI values may also be used to carry out the water sorptivity test to determine porosity and sorptivity. Sorptivity is a measure of the capacity of concrete specimen to absorb water. The water sorptivity of concrete is determined from the slope the straight line produced from plotting a linear relationship between the mass of water against the square root of time [1]. Cores are to be placed in solution as indicated in Figure 3 to determine porosity.

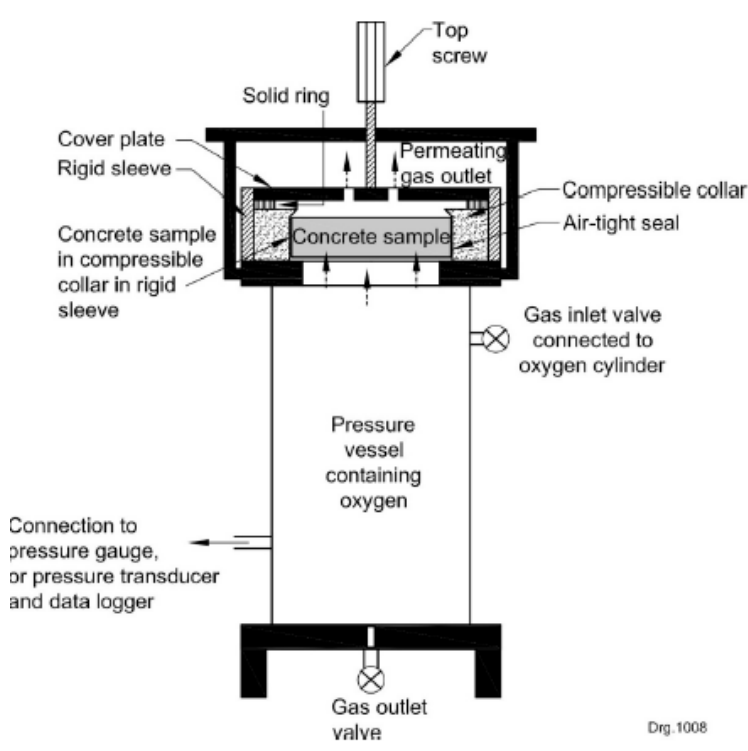

Figure 2: Permeability cell arrangement [2] 


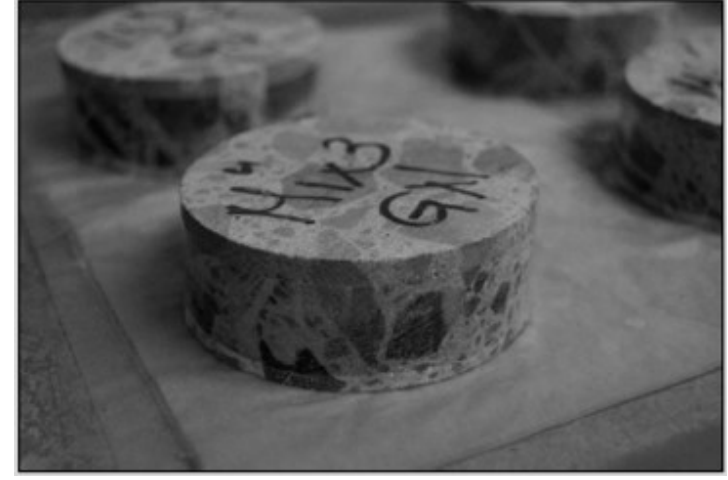

Figure 3: Concrete core with proper solution depth [2]

\subsection{Chloride conductivity test}

The Chloride Conductivity Index test uses an electrical circuit to determine the chloride conductivity of concrete [21]. Diffusion is a slow process that could potentially take months or years. The accelerated diffusion test using an applied potential difference of $10 \mathrm{~V}$ has therefore been developed to obtain more instantaneous results in the laboratory [1]. Figure 4 illustrates the set up to carry out the test. The chloride conductivity is determined by measuring the current flowing through the concrete specimen. Chloride conductivity decreases with the addition of FA, GGBS, and CSF in concrete, extended moist curing and increasing grade of concrete [1].

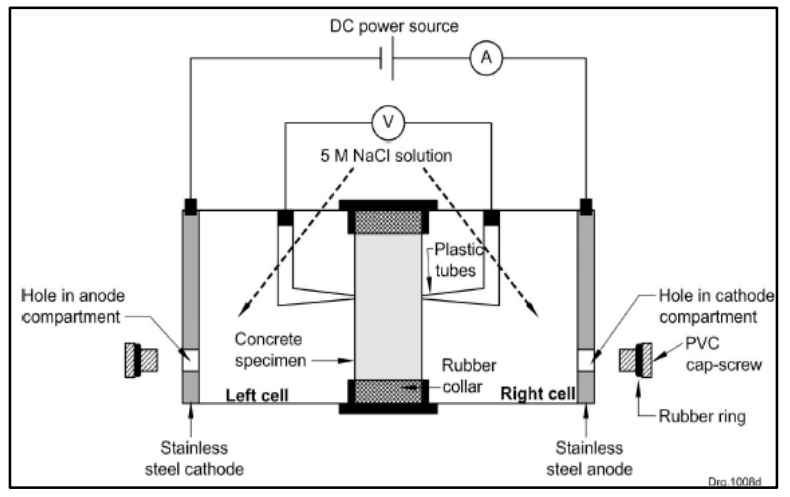

Figure 4: Simple cell arrangement [2]

\section{Conclusion}

Sasol Ashes are expected to exhibit similar fresh and hardened properties to FA when used as cement extenders. The deviation in behaviour for both WFA and CGA blended specimen from the 100PC will be measured and compared to that of FA blended specimen. This investigation will advance the knowledge of Sasol ashes. This knowledge would assist in the consideration of Sasol ashes as a cement extender. The positive utilization of Sasol ashes as cement extenders would result in the transformation WGA and CGA from being a by-product due only for disposal. Sasol ashes as cement extender would result in a positive impact on the environment. The by-products will not be left to continuously accumulate and the demand for cement would reduce resulting in lessened $\mathrm{CO}_{2}$ emissions.

The authors would like to acknowledge The Concrete Institute, PPC Pty Ltd, AfriSam, NRF and Aurecon for the support towards this study.

\section{References}

1. Ballim, Y., Alexander, M., \& Beushausen, H. (2009). Durability of concrete. In G. Owens (Ed.), Fulton's Concrete Technology (p. 155). Midrand: Cement and Concrete Institute.

2. Department of Civil Engineering. (2017). Durability Index Manual. Retrieved from http://www.comsiru.uct.ac.za/sites/default/files/ image tool/images/333/Downloads/UCTWITS\%20DI\%20Manual_2017\%20Ver\%204.2 \%202017-07-14.pdf

3. Ginster, M., \& Matjie, R. H. (2005). Beneficial Utilisation of Sasol Coal Gasification Ash. Lexington: 2005 World of Coal Ash (WOCA).

4. Grieve, G. (2009). Cementitious materials. In G. Owens (Ed.), Fulton's Concrete Technology (p. 1). Midrand: Cement \& Concrete Institute.

5. Islam, M. M., \& Islam, M. S. (2010). Strength Behaviour of Mortar Using Fly ASh as Partial Replacement of Cement. Concrete Research Letters, 1(3), 98 - 106.

6. Julie Kerr Casper, P. (2010). Changing Ecosystems: Effects of Global Warming. New York: Facts On File, Inc.

7. Kruger, J. E. (1987). Research at the NBRI on the utilisation of fly ash: An overview. (In) Proceedings of Symposium: Ash - a valuable resource, 2.

8. Kruger, J. E. (2003). South African Fly Ash: A Cement Extender. Johannesburg: The SOuth African Coal Association.

9. Kuo, L. (2015). Africa's richest man plans to almost double the continent's cement production by 2020. Retrieved July 11, 2016, from http://qz.com/489417/africas-richest-manplans-to-almost-double-the-continents-cementproduction-by-2020/

10. Lesch, W., \& Cornell, D. H. (1987). The mineralogy and morphology of fly ash from South African power stations. Ash - a valuable resource, first national symposium, 3 .

11. Mahlaba, J. S., Kearsley, E. P., \& Kruger, R. A. (2011). Physical, chemical and mineralogical characterisation of hydraulically disposed fine coal ash from SASOL Synfuels. 1-10. Pretoria: ScienceDirect.

12. Mahlaba, S. J. (2006). Evaluation of paste technology to co-dispose of ash and brines at Sasol synfuels complex. Johannesburg: University of Witwatersrand.

13. Matjie, R. H., Ginster, M., \& Ratale, H. (2005). Beneficial Utilisation of Sasol Coal 
Gasification Ash. Lexington: 2005 World of Coal Ash (WOCA).

14. Matjie, R. H., Ginster, M., van Alphen, C., \& Sobiecki, A. (2005). Detailed Characterisation of Sasol Ashes. Johannesburg: Sasol Technology (Pty) Ltd and Van Alphen Consultancy.

15. Owens, G. (2009). Fulton's concrete technology (9th edition ed.). Midrand: Cement \& Concrete Institute.

16. Perrie, B. (2009). Strength of Hardened Concrete. In G. Owens (Ed.), Fulton's Concrete Technology (p. 97). Midrand: Cement and Concrete Institute.

17. Roy, W. R., Thiery, R. G., Schuller, R. M., \& Suloway, J. J. (2012). Coal fly ash: a review of the literature and proposed classification system with emphasis on environmental impacts. Champaign:

http://archive.org/details/coalflyashreview96roy w.
18. Sideris, K. K., \& Konsta-Gdoutos, M. (1996). Influence of the Water to Cement Ratio W/C on the Compressive Strength of Concrete - An Application of the Cement Hydration Equation to Concrete. Applied Composite Materials, 3, 335-343.

19. Silfwerbrand, J. (2012). Sustainable concrete is more than just durable concrete. Structural Concrete, 13(1), 1-2.

20. South African Bureau of Standards. (2015). SANS3001-CO3-2. Pretoria: South African Bureau of Standards.

21. South African Bureau of Standards. (2015). SANS3001-CO3-3. Pretoria: SABS.

22. Standards, S. A. (2015). SANS 3001- CO3-2. South African Bureau of Standards.

23. Vadapallia, V., Klinkb, M., Etchebersa, O., Petrika, L., Gitaria, W., Whitec, R., \& Iwuohab, D. K. (2008). Neutralization of acid minedrainage using fly ash, and strength development of the resulting solid residues. South African Journal of Science, 104, 317-322. 